Central European Geology, Vol. 56/1, pp. 75-81 (2013)

DOI: 10.1556/CEuGeol.56.2013.1.6

\title{
10th Applied Isotope Geochemistry Conference, Late Abstracts
}





\title{
Contemporary ${ }^{14} \mathrm{C}$ radiocarbon levels of oxygenated polybrominated diphenyl ethers (O-PBDEs) isolated in Sponge-Cyanobacteria associations
}

\author{
Carlos Guitart ${ }^{1,5}$, Marc Slattery ${ }^{2,3}$, Sridevi Ankisetty ${ }^{2}$, Mohamed Radwan ${ }^{3}$, \\ Samir J. Ross ${ }^{3}$, Robert J. Letcher ${ }^{4}$, Christopher M. Reddy ${ }^{1}$ \\ ${ }^{1}$ Dept. of Marine Chemistry and Geochemistry, Woods Hole Oceanographic Institution, Woods Hole, \\ MA 02543, USA \\ ${ }^{2}$ University of Mississippi, Department of Pharmacognosy, Oxford, USA \\ ${ }^{3}$ University of Mississippi, National Center for Natural Products Research, Oxford, USA \\ ${ }^{4}$ Ecotoxicology and Wildlife Health Division, Wildlife and Landscape Science Directorate, Science and \\ Technology Branch, Environment Canada, National Wildlife Research Centre, Carleton University, \\ Ottawa, Ontario, Canada \\ ${ }^{5}$ Instituto Español de Oceanografía - IEO, Centro Oceanográfico de Murcia, Murcia, Spain
}

Considerable debate surrounds the sources of oxygenated polybrominated diphenyl ethers (O-PBDEs) in wildlife as to whether they are naturally produced or result from anthropogenic industrial activities. Natural radiocarbon $\left({ }^{14} \mathrm{C}\right)$ abundance has proven to be a powerful tool to address this problem as recently biosynthesized compounds contain contemporary (i.e. modern) amounts of atmospheric radiocarbon; whereas industrial chemicals, mostly produced from fossil fuels, contain no detectable ${ }^{14} \mathrm{C}$. However, few compounds isolated from organisms have been analyzed for their radiocarbon content. To provide a baseline, we analyzed the ${ }^{14} \mathrm{C}$ content of four O-PBDEs. These compounds, $6-\mathrm{OH}-$ BDE47, 2'-OH-BDE68, 2',6-diOH-BDE159, and a recently identified compound, 2'MeO-6-OH-BDE120, were isolated from the tropical marine sponges Dysidea granulosa and Lendenfeldia dendyi. The modern radiocarbon content of their chemical structures (i.e. diphenyl ethers, $\mathrm{C}_{12} \mathrm{H}_{22} \mathrm{O}$ ) indicates that they are naturally produced. The existence of potentially different sources of O-PBDEs in the environment (i.e. synthetic, natural and transformed), challenges the issue of the source and the potential risks to exposed wildlife. Therefore, elucidation of sources is a key to understanding the environmental occurrence, transformation processes, transport processes and bioaccumulation of O-PBDEs. The molecular level radiocarbon technique (by Accelerator Mass Spectrometry, AMS) allows discriminating between these origins. The baseline data presented in this study provides evidence of natural production in marine sponge-bacteria associations.

References

Guitart, C., M. Slattery, S. Ankisetty, M. Radwan, S.J. Ross, R.J. Letcher and C.M. Reddy,

"Contemporary $14 \mathrm{C}$ radiocarbon levels of oxygenated polybrominated diphenyl ethers (O-

PBDEs) isolated in sponge-cyanobacteria associations", Mar. Poll. Bull., 62, pp.631-636, 2011

Reddy, C.M., L. Xu, R.K. Nelson, T.I. Eglinton, D.J. Faulkner, R. Norstrom, P.S. Ross, S.A. Tittlemier,

"Radiocarbon evidence for a naturally produced, bioaccumulating halogenated organic

compound. Env. Sci. Technol., 38, pp.1992-1997, 2004 


\title{
Compound-specific chlorine isotope analysis in contaminant hydrogeology
}

\author{
Daniel Hunkeler ${ }^{1}$, Florian Breider ${ }^{1}$, Simon Jeannottat ${ }^{1}$, Martin Elsner ${ }^{2}$, \\ Orfan Shouakar-Stash ${ }^{3}$, Ramon Aravena ${ }^{3}$ \\ ${ }^{1}$ Centre for Hydrogeology and Geothermics (CHYN), Université de Neuchâtel, Neuchâtel, \\ Switzerland, e-mail: Daniel.Hunkeler@unine.ch \\ ${ }^{2}$ Helmholtz Zentrum München, Neuherberg, München, Germany \\ ${ }^{3}$ University of Waterloo, Waterloo, Canada
}

Organic compounds are among the most commonly detected groundwater contaminants. Compound-specific isotope analysis (CSIA) can provide unique insight into their origin and fate in the subsurface. Recent advances in analytical methods have opened new possibilities for the application of CSIA to chlorinated contaminants, which are of particular concern due to their high toxicity and persistence in the environment. This presentation provides an overview of the current understanding of the chlorine isotope behaviour during physical and reactive processes, and illustrates the application of chlorine isotope methods in contaminant hydrogeology.

A characteristic feature of chlorine isotopes is the high abundance of the heavy isotope $\left({ }^{37} \mathrm{Cl}\right)$. While this has made it possible to use conventional GC-quadrupolMS for high precision isotope analysis 1, it complicates data interpretation as multiple isotopologues need to be taken into account. However, it can be shown that during many physical and reactive processes, pairs of isotopologues with different numbers of heavy chlorine isotopes fractionate proportionally in good approximation. This makes it possible to relate isotopologue ratios to isotope ratios using simple expressions and simplifies analytical procedures.

In addition, a novel application of isotope analysis to differentiate between natural and anthropogenic chloroform in groundwater will be presented. Due to its origin from natural organic matter, natural chloroform has a distinctly different carbon isotope signature ( -20 to $-30 \%$ ) compared to anthropogenic chloroform ( -40 to $-60 \%$ ), which is based on methane 2 . However, during its migration through the subsurface, the isotopic signature can be altered significantly due to the strong isotope fractionation associated with reductive dechlorination of chloroform. However, a dual carbon-chlorine isotope approach makes it possible to differentiate between natural and anthropogenic chloroform even if biodegradation occurs.

\section{References}

1. Bernstein, A.; Shouakar-Stash, O.; Ebert, K.; Laskov, C.; Hunkeler, D.; Jennottat, S.; Sakaguchi-Soder, K.; Cretnik, S.; Jager, J.; Haderlein, S. B.; Aravena, R.; Elsner, M., Compound-specific chlorine isotope analysis: An interlaboratory comparison of gc-irms and gc-qms methods. Anal. Chem. 2011, 83, (20), 7624-7634.

2. Hunkeler, D., Laier, T., Breider, F. \& Jacobsen, O. S., 2012. Demonstrating a natural origin of chloroform in groundwater using carbon isotopes. ES\&T. 46, 6096-6101. 


\title{
Lead isotope signature of Mesozoic and Cenozoic ore deposits in Northern Tunisia
}

\author{
Nejib Jemmali ${ }^{1}$, Fouad Souissi ${ }^{1}$, Emmanuel John Carranza ${ }^{2}$, \\ Jean Jacques Orgeval ${ }^{3}$ \\ ${ }^{1}$ Université de Tunis El Manar, Faculté des Sciences, Département de Géologie, Tunis, Tunisia, \\ Laboratoire des Matériaux Utiles, Institut National de Recherche et d'Analyse Physico-chimiques, \\ 2026 Technopole de Sidi Thabet, Tunisia, e-mail: nejib.jemmali@yahoo.fr \\ ${ }^{2}$ Economic Geology Research Unit, School of Earth and Environmental Sciences, James Cook \\ University, Townsville, Queensland, Australia \\ ${ }^{3}$ Bureau de Recherches Géologiques et Minières, Département Exploration, BP 36009/45060 - Orléans \\ Cedex 2- France
}

In Northern Tunisia, sediment-hosted $\mathrm{Pb}-\mathrm{Zn}$ deposits are found mainly in the following four structural zones from the northwest to the southeast of the fold belt: the Nappes zone, the Diapirs zone (or Triassic Domes zone), the Trough zone and the Jurassic Mountains zone (Fig. 1). The majority of ore deposits and occurrences are: (i) $\mathrm{Pb}-\mathrm{Zn}$ mineralization with arsenic and antimony hosted in the continental Neogene volcanics or situated immediately below them (Jebel Hallouf-Sidi Bou Aouane, Jalta, Bechateur); (ii) Pb-Zn mineralization with arsenic and mercury in fractures with local intrusions related to the Neogene volcanics (Fej Hassene, Oued Maden); (iii) stratabound lenticular orebodies in the contact zone (or transition zone) between Triassic and Cretaceous strata (Bou Grine, Guern Halfaya); (iv) stratabound orebodies associated to Cenomanian-Turonian strata (Bou Grine, Guern Halfaya); (v) veins, stockworks and open-space fillings developed in the peridiapiric cover (Bou Grine, Fedj-el-Adoum); (vi) stratabound or stratiform bodies, either within or immediately above the Jurassic reef limestones of Kimmeridgian-Tithonian-Berriasian age (Hammam Zriba, Jebel Ressas, Jebel Mecella), along unconformity surfaces highlighted by shoals, condensed layers, stratigraphic gaps, karstification and pedogenesis, that separate Ressas Formation from overlying units. Pb-isotopic composition of galena display an homogeneous lead isotope signature $\left({ }^{206} \mathrm{~Pb} /{ }^{204} \mathrm{~Pb}\right.$ : $18.723-19.002$ and ${ }^{207} \mathrm{~Pb} / 204 \mathrm{~Pb}$ : 15.663-15.700; Fig. 2) suggesting a single lead reservoir for deposits of the Domes and Jurassic Mountain zone, and a mixing lead reservoir for the Nappes zone. $\mathrm{Pb}$ isotope values of deposits of Jurassic Mountains zone are slightly more radiogenic than lead from the other deposits, possibly reflecting the influence of a more evolved upper crustal source. The homogeneous lead and the lack of extensive wall-rock alteration suggests that the lead was not leached from the country rocks. Underlying Paleozoic sediments are proposed as lead source for mineralization in all ore deposits. Model-lead ages are about 12,5-13 Ma and $86 \mathrm{Ma}$ for the Nappes zone and Diapirs zone, respectively, whereas in the Jurassic Mountain zone, the age is not in accordance with the geological settings. 
Fig. 1

The Triassic exposures and $\mathrm{Pb}-\mathrm{Zn}$ deposits in Northern Tunisia

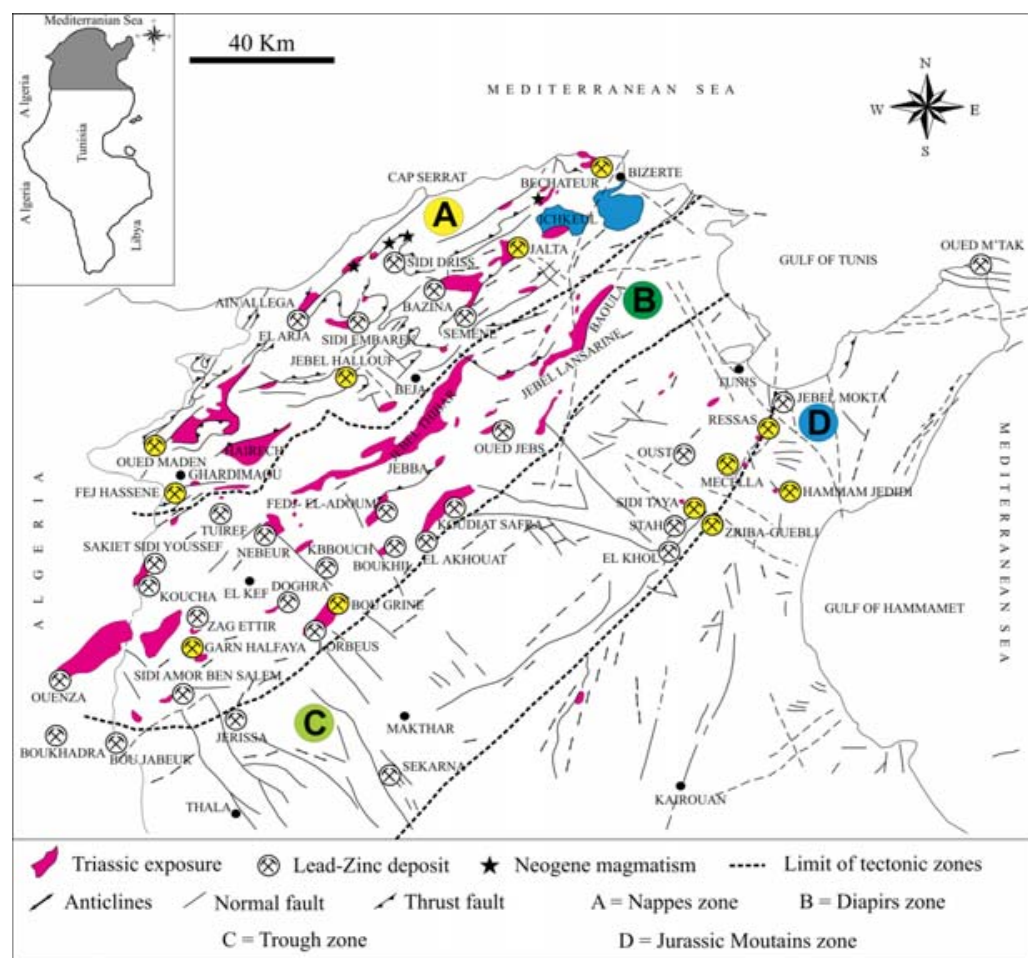

Fig. 2

Plots of

${ }^{207} \mathrm{~Pb} / 204 \mathrm{~Pb}$

vs.

${ }^{206} \mathrm{~Pb} / 204 \mathrm{~Pb}$ for the $\mathrm{Pb}-\mathrm{Zn}$ deposits in

Northern

Tunisia.

Curves of

growth trends for $\mathrm{Pb}$ isotope ratios are

from the

plumbotecton

ic model of

Zartman and

Doe (1981).

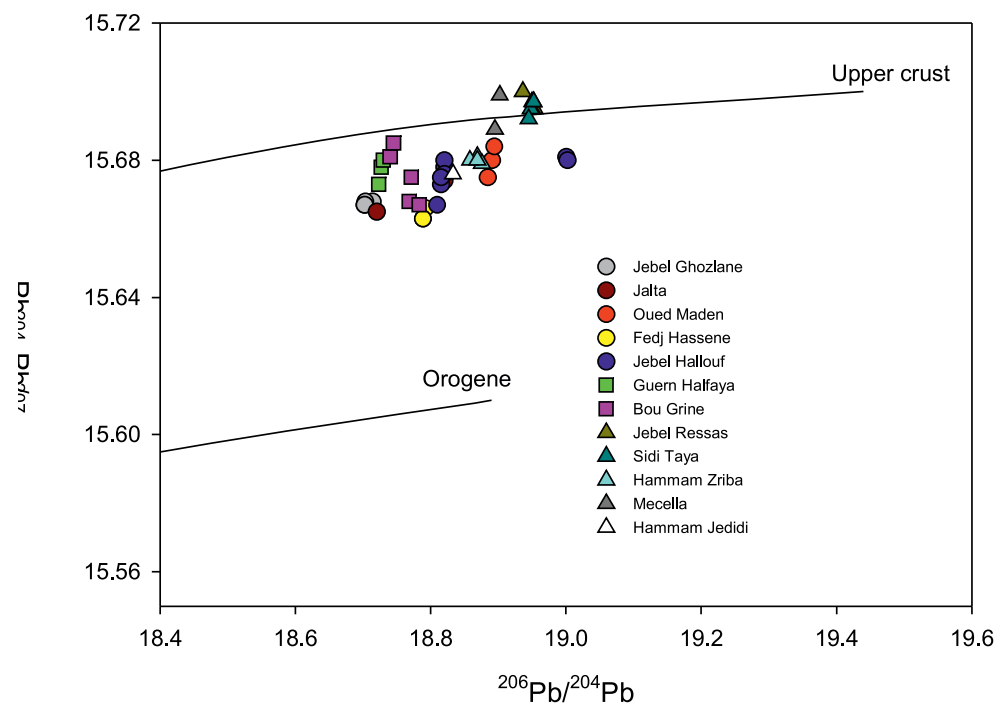

References

1. R.E. Zartman, R.E., B.R. Doe. Plumbotectonics — the model. Tectonophysics 75, pp. 135-162. 1981 


\title{
Role of mantle/magmatic derived auriferous fluid for Archean Orogenic Gold deposits from Sangli mine area, Gadag Schist Belt, South India - Evidence from C-O stable isotope and fluid inclusion study
}

\author{
S.K. Swain ${ }^{1}$, S. Sarangi ${ }^{1}$, A.Sarkar ${ }^{2}$, R. Srinivasan ${ }^{3}$ \\ ${ }^{1}$ Department of Applied Geology, Indian School of Mines, Dhanbad 826 004, India \\ ${ }^{2}$ Department of Geology and Geophysics, Indian Institute of Technology, Kharagpur 721302, India \\ ${ }^{3} 114$, Kshithija, Ramanashree Nagar, Bannerghatta Road P.O., Bangalore 560007, India
}

Carbon $\left(\delta^{13} \mathrm{C}_{\mathrm{pdb}}\right)$ and Oxygen $\left(\delta^{18} \mathrm{O}_{\text {smow }}\right)$ isotopic compositions of auriferous quartz carbonate veins (QCVs) of orogenic gold deposits from Sangli mine area, Gadag gold deposit of the Archaean Gadag Schist Belt, Dharwar Craton, Karnataka have been examined for the first time in this deposit to understand the origin of the mineralizing fluids. The average $\delta^{13} \mathrm{C}_{\mathrm{pdb}}$ and $\delta^{18} \mathrm{O}_{\text {smow }}$ isotope compositions of auriferous QCVs are $-4.5 \%$ ( $\pm 2.5 \%$ o), $24.26 \%$ ( \pm 5.2$)$ respectively. However, $\delta^{13} \mathrm{C}$ data of only 5 samples out of 36 number of samples analysed, range within those of metasedimentary carbonates reported from Chitradurga Schist belt (i.e. 0 to $-2 \%$, Das Sharma et al. 1994). Most of the $\delta^{13} \mathrm{C}$ values of carbonates of QCVS are well within the $\delta^{13} \mathrm{C}$ range of carbonates or $\mathrm{CO}_{2}$ derived from magma $(-5+3 \%$; Burrows et al. 1986) or mantle $(6+2 \%$; Ohmoto, 1986). Hence, it is proposed that the fluids responsible for gold mineralisation in the area under study could have been derived from multiple sources. The major source could be from mantle and/or magma and a very minor component might have been derived from metamorphic devolatilisation of pre-existing sedimentary rocks.

References

1. Burrows DR, Wood PC, Spooner ETC (1986) Carbon isotope evidence for a magmatic origin for Archaean gold quartz vein ore deposits. Nature 321: 851-854.

2. Das Shrama S, Srinivasan R, Ahmad SM, Patil DJ (1994) Carbon and oxygen isotopic compositions of regionally metamorphosed Archaean carbonate rocks of the Dharwar craton. Curr Sc 66: 857-860.

3. Grooves DI, Goldfarb RJ, Robert F (1998) Orogenic gold deposits: A proposed classification in the context of their crustal distribution and relationship to other gold deposit type. Ore Geology Rev 13: 7-28.

4. Ohmoto H (1986) Stable isotope geochemistry of ore deposits. In stable isotopes in high temperature geological processes. Edited by J. W. Valley, H.P. Taylor, Jr and O’Nell. Mineralogical Society of America, Rev Miner 16: 491-560. 